\title{
Promoting Food for the Trash Bin? A Review of the Literature on Retail Price Promotions and Household-Level Food Waste
}

\author{
George Tsalis ${ }^{1, *}$, Birger Boutrup Jensen ${ }^{1}$, S. Wiley Wakeman ${ }^{2} \mathbb{D}$ and Jessica Aschemann-Witzel ${ }^{1}$ \\ 1 MAPP Centre-Research on Value Creation in the Food Sector for Consumers, Industry and Society, \\ Department of Management, Aarhus University, Fuglesangs Allé 4, 8210 Aarhus V, Denmark; \\ bbj@mgmt.au.dk (B.B.J.); jeaw@mgmt.au.dk (J.A.-W.) \\ 2 Centre for Retailing, Department of Management and Organization, Stockholm School of Economics, \\ Box 6501, SE-113 83 Stockholm, Sweden; wiley.wakeman@hhs.se \\ * Correspondence: tsalis@mgmt.au.dk; Tel.: +45-8716-6115
}

Citation: Tsalis, G.; Jensen, B.B.; Wakeman, S.W.; Aschemann-Witzel, J. Promoting Food for the Trash Bin? A Review of the Literature on Retail Price Promotions and Household-Level Food Waste. Sustainability 2021, 13, 4018. https://doi.org/10.3390/su13074018

Academic Editor: Ada Margarida Correia Nunes Da Rocha

Received: 10 February 2021

Accepted: 11 March 2021

Published: 4 April 2021

Publisher's Note: MDPI stays neutra with regard to jurisdictional claims in published maps and institutional affiliations.

Copyright: (c) 2021 by the authors. Licensee MDPI, Basel, Switzerland. This article is an open access article distributed under the terms and conditions of the Creative Commons Attribution (CC BY) license (https:// creativecommons.org/licenses/by/ $4.0 /)$.
Abstract: Supermarkets receive criticism for irresponsible marketing practices, such as price promotions, that trigger over-purchasing and seemingly contribute to consumer waste. In the wake of this, retailers have abolished certain price promotions as part of an effort to meet corporate social responsibility (CSR) goals. We aim to investigate whether the underlying assumption that price promotions are positively related to consumer food waste needs to hold true. Through a review of the existing literature, we show that there is no scientific consensus on this assumption. Our findings show that half of the studies conclude that price promotions result in food waste by encouraging over-purchase, while the remaining conclude that consumers buying price-promoted food products show average or even lower levels of household food waste. Unraveling this inconsistency, we contribute by proposing a multi-level model of CSR behavior, where CSR actions at an institutional level (retailer) interact with individual characteristics at a micro (consumer) level leading to demonstrably different outcomes. We argue that the assumption that price promotions necessarily cause food waste has been overly simplistic, as it did not take into account the consumers' role. We conclude that the relationship between price promotions and consumer food waste is conditional on price consciousness, attitudes, values, household identities, and household roles. Thus, we illustrate that CSR problems are often wicked ones, where first-order solutions often lead to secondary problems that stymie the progress of institutions and policy makers in addressing social needs in business. We derive specific recommendations for retailers seeking to meet CSR goals.

Keywords: food waste; retailing; corporate social responsibility (CSR); consumer social responsibility (CnSR); corporate ethics; consumer behavior; price promotions

\section{Introduction}

The issue of food waste has received increased attention in the past few years. Not only have governments and international nongovernmental organizations (NGOs) prioritized this issue, but local food market actors have seen value in addressing this problem, enacting potential solutions for reducing food waste at all stages of the food supply chain. "Halving food waste" has been listed among the measures that can help to achieve the sustainable development goals [1]. Although food waste estimates vary [2,3], assessments indicate that approximately $25 \%$, or $614 \mathrm{kcal} / \mathrm{cap} /$ day, of the produced crop supply is lost within the food supply chain alone [4], and approximately one third of the food that is produced for human consumption, or roughly 1.3 billion tons, is wasted overall $[5,6]$. This contributes to about $30 \%$ of greenhouse gas emissions [7] and is playing a significant role in climate change. Moreover, food waste is also regarded as a social inequality issue, helping to perpetuate inequalities in the global food supply [8], and a financial drain on economies where an estimated $\$ 936$ billion is lost due to unconsumed food [9]. Thus, it becomes clear that to meet socially desirable outcomes, food waste is a significant issue to address. 
Who is to blame for food waste? Research suggests that a large share of it occurs in consumer households [10]. The amount of avoidable food waste in households, i.e., food that was perfectly edible prior to disposal [11], has been estimated to represent as much as $50 \%$ of total food waste in Europe [4,12] and 60\% in the US [13], whereas food waste at the retail stage is estimated to be only about $5 \%$ of the food waste in developed countries [14]. The conclusion from this seems to be that consumers themselves play a significant role in the production of food waste [15]. But are consumers the only actors that contribute to food waste?

Research also points to the important role that retailers play in the production of food waste due to the power they wield both within the supply chain [16] and on the retail-consumer interface [17]. For instance, retailers often make strategic decisions on standards of appearance [18,19], which influence how consumers expect food should look [20], and retailers also decide on the size of the product units they sell, or the breadth of an assortment offered. These are decisions that can ultimately contribute to food waste in the supply chain [16]. Importantly, and central to our exploration, retailers enact pricing tactics, and these have been blamed for triggering over-purchasing that contributes to food waste $[21,22]$.

In the wake of the knowledge that retailers play an important role when considering food waste concerns, retailers have begun to take action against food waste with a variety of initiatives, e.g., information and awareness initiatives, redistribution of excess food $[23,24]$, including the abolishment of "buy one get one free" (BOGOF) price promotions [25,26]. At face value, these actions are socially responsible in so much as they integrate social concerns in business operations in order to alleviate the environmental and social impacts of businesses [27]. Yet, if abolishing BOGOF price promotions is done with the explicit goal of avoiding food waste, then the retailer should ensure that these actions effectively reduce food waste. Thus, the aim of this research is to provide substantive evidence, within the existing scientific literature on food waste, of the relationship between retail price promotions and consumer-level food waste.

The remainder of the article is organized as follows: The first section presents a background on the overall relation between retail price promotions, consumers, and food waste, as well as an analysis into corporate social responsibility (CSR) goal conflicts for the stakeholder groups of consumers, companies, and society. Following this, we describe the methodology of the literature review, helping to answer the research question "are retail price promotions and household-level food waste negatively or positively related?" We then describe the findings and discuss the factors suggested by the research articles as moderators of the relationship between price promotion and food waste. Lastly, we discuss the implications and develop recommendations for responsible retail marketing practices, as well as future directions for research.

\subsection{Consumers, Food Journey, and Food Waste and the Role of Price Promotions}

The causes of food waste in consumer households are complex and interrelated [28,29]. Research has shown that consumers experience negative emotions and guilt with regards to food waste [8]. Therefore, it can be assumed that consumers do not plan for food to be wasted. Rather, consumers might, for example, plan for a certain over-supply of food in their homes, aspiring toward being a "good provider" [30], but have these plans interrupted by unpredictable events. As research shows, food waste occurs due to goal conflicts (e.g., eating to avoid food waste, versus not eating, to adhere to a diet or to eat something more appealing) caused by the various motives behind food purchases and the distinct roles food plays in daily life [31]. In addition, food waste also results from shortcomings and the lack of capabilities in planning, food handling, or preparation [32,33].

There is a wide heterogeneity in how the concept of food waste is defined in research [34]. The majority of definitions describe food waste as the discard of edible food that is still suitable for human consumption [35]. These definitions range from general definitions, e.g., "[ ... ] the food brought home or prepared at home but not consumed" [36], 
to more elaborate ones, e.g., "[ . . ] the surplus food that is not recovered to feed people, to feed animals, to produce new products (e.g., jams or juices), new materials (e.g., fertilizers) or energy" [37]. However, some researchers expand the definition of food waste by including excessive caloric intake through the overconsumption of food beyond the average human metabolic capacity of approximately $2000 \mathrm{kcal} /$ day $[2,38,39]$. Thus, according to this perspective, not only discarded food but also food that is eaten beyond nutritional and caloric necessity, when accounting for the level of physical activity and special caloric demands, can constitute food waste.

There is also, however, the intermediate stage of storage in which most foods remain after purchase. Food storage facilities and behavior have been observed to play a role in food waste. Evans [40], for example, argues that disposal of food in the household happens via a gradual process in which devices whose purpose is to preserve foods, such as freezers, often "[ ... ] operate as coffins of decay that play an active part in carrying discarded food towards the waste stream." Similarly, Waitt and Phillips [41] draw attention to the fact that consumers postpone consumption and store foods that, with time, become revalued as excess and are discarded.

Taking a broader perspective, with the aim to illustrate an expansive view of food waste and of what can conceptually be regarded as food waste, we therefore note that food waste is not only what is observable in households' trash bins but also as excessive calorie storage in the human body as a result of excessive food consumption. What is stockpiled in fridges, refrigerators, and other food preservation conduits might or might not become food waste, depending on how the foods' journey progresses, and how the consumer decides about its further use. Figure 1 offers a visualization of the paths where foods can become waste as an outcome of reacting favorably to a price promotion at the retail level. A path may potentially begin via a period of stockpiling, and then waste may be manifested either as food discard or as overconsumption. Table A1 in Appendix A provides examples of the different conceptualizations of food waste.

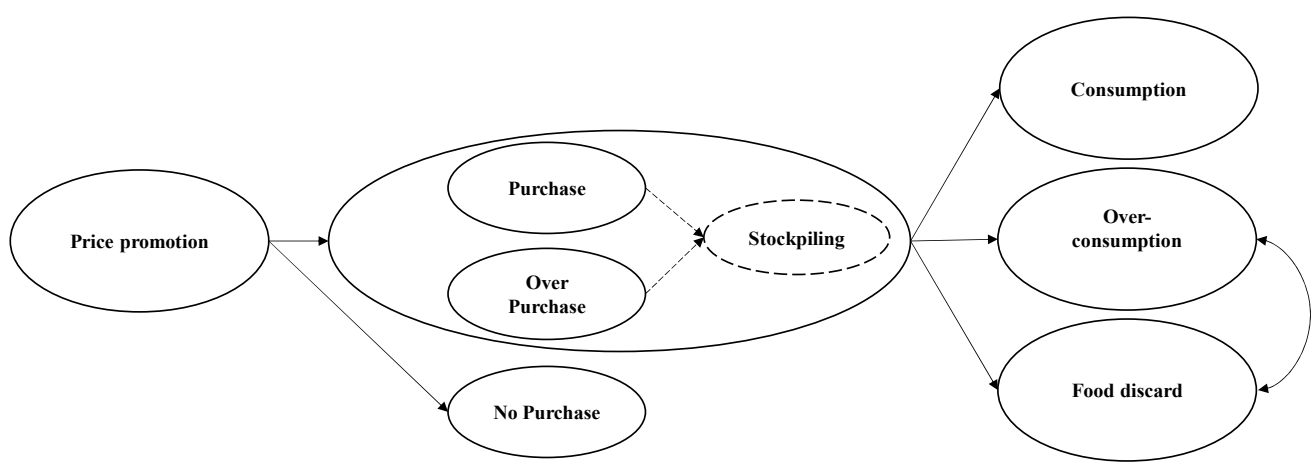

Figure 1. Conceptual framework of the relations between price promotions and food waste.

The price of food plays a particularly important role for the issue of food waste, and it does so through various connections. It is often mentioned that the overall low level of food prices in developed countries leads to an under-valuation of food by consumers and a disregard of the natural resources that have been used to produce it $[8,28]$. Moreover, people may be able to waste food because the proportion of income that is allocated to food declines as the income level in the western world increases [42]. Food is often purchased without much thought, given that in marketing terms, it is a low-involvement, fast-moving consumer good to many customers [43]. When grocery shopping, consumers might search for good deals on food much more as part of their self-identity than for reasons of economic need [44,45]. In addition to the low overall price level and low valuation of food, pricing mechanisms - such as BOGOF offers, multi-item offers, and a price gradient more favorable to large unit sizes-in food marketing can trigger consumers to over-purchase and over-stock food items because it becomes economically cheaper to purchase larger units [19,46,47]. 
Interestingly, however, pricing mechanisms are also suggested as a means to tackle the problem of food waste, with the application of price reductions of suboptimal food allowing the sale of food that would otherwise be wasted at the retail level. Suboptimal foods are foods that deviate from normal in appearance, date labeling (e.g., close to expiration date), and packaging (e.g., presence of dents) [48]. Many retailers have begun to mark such suboptimal foods with specially designed stickers, not only communicating the price reduction but also the food waste avoidance, thus positioning the action as contributing to the CSR objectives [24]. However, this raises the question whether pricing can be given part of the blame for food waste but then used to combat it as well-and whether pricing really causes that much food waste in the first place. A plausible reasoning to the opposite end is that consumers who specifically seek out price promotions might not necessarily always waste food: First, because they face economic constraints, and second, because they are conservative and cautious with what they have bought. In that sense, the use of price promotions might not necessarily trigger wastage, as wastage might depend on the type of consumer.

\subsection{Corporate Social Responsibility, CSR Goal Conflicts, and Food Waste}

Food waste is a sustainability issue with societal consequences, and a topic that raises questions about the ethics of marketing [16,49]. If the responsibility of retailers were purely "business" [50], companies would focus on maximizing their own benefit and not care about what happens to the food after it is successfully sold. Food waste would then be a necessary evil that contributes to the end goal of increasing sales volume and thus business growth. However, from the corporate social responsibility perspective [51], the adverse effects of food waste in terms of negative environmental and social impact should trigger businesses to act responsibly on behalf of the society as a whole by altering their business and marketing actions accordingly. Carroll [52,53] argues that an organization needs to meet the ethical, economic, legal, and philanthropic expectations of society in order to be considered socially responsible, including when addressing issues surrounding food waste [16]. These societal expectations function as CSR bellwethers and should eventually be adopted by organizations that wish to be considered socially responsible.

However, these multiple expectations create goal conflicts. Hunt and Vitell [54] mention that marketing decisions when determining their ethical judgements should aim to fulfill the joint requirements of utility and justice, while facing the problem of a possible conflict between the two. Should retailers promote their own greatest good (ethical egoism), or strive for a greater balance of good over bad consequences for all of society (ethical universalism)? The relationship between retail price promotions and household food waste, as well as the actions taken by retailers on the matter, lie within the realm of teleological theories of moral philosophy, where the primary focus is put on the amount of value the end result brings to define whether an action is right [54]. Some retailers have abolished price promotions at the store based on the belief that price promotions cause food waste at the household level, thus justifying the action of abolishing an otherwise economically efficient practice (price promotions), as a means to a societally desirable end (food waste reduction).

However, normative prescriptions as for how retailers should fulfill their ethical obligations to society should stem from a deeper understanding of the phenomena that lie in the epicenter of the ethical discourse, which in this particular case, is whether or not retail price promotions lead to an increased amount of household food waste. A deeper understanding is needed in order to ascertain if price promotions are condemnable, as well as because causal relations between means and end are rarely that simple.

Vitell [55] argues that in order to maximize social benefits, corporate and consumer interests should align and emphasize the importance of consumers' social responsibility (CnSR) as a factor that plays a synergistic role in the success of CSR. With the application of price promotions, both retailers and consumers' interests align in ways that benefit them both, but possibly negative externalities (food waste) occur nonetheless. For instance, price 
promotions provide a conduit for retailers to sell more in order to fulfill their financial goals (meeting retailer economic goals), and for consumers to make more out of their limited budgets (meeting consumer economic goals). Thus, price promotions and food waste do not affect consumers or retailers negatively, but have wider societal effects, (the possible occurrence of food waste) which call for corporate as well as consumer social responsibility.

Some retailers within their CSR initiatives have abolished multi-item offers on the grounds that they trigger food waste, and by doing so, they have gained an improved corporate social responsibility (CSR) image [25]. However, in order for this initiative to be an effective step in line with the multiple aspects of CSR, its positive outcome-food waste avoidance-should be greater than its negative side-effects, such as the decrease in sales and reduced access to good deals for budget-constrained customers. Otherwise, the CSR action becomes mere "window dressing" or "green-washing," and does not fulfil the actual goal of CSR. The same critical question can be asked about price promotion on suboptimal foods otherwise wasted in store: If price promotions lead to over-purchase and consequently food waste, then this would surely also apply to price-reduced suboptimal foods, which then might be wasted at home instead of in the store. Are retailers then claiming that they make an effort toward reducing food waste, reaping the benefits of a favorable reputation as a good corporate citizen, while simultaneously contributing to an increased amount of food waste with the use of price promotions? Another example of the complication of the issue is the fact that retailers are increasingly encouraged to promote healthy eating and increased consumption of fruits and vegetables that are highly perishable. Such initiatives, however, could increase the probability of food waste. Should retailers therefore reduce the availability of fresh produce, or increase availability of processed foods with longer shelf lives in order to avoid food being wasted?

What becomes apparent with these questions is that the implementation of one CSR action can possibly nullify another, due to the multiplicity and conflict of the purposes it sets out to serve. Therefore, CSR actions aimed at serving one goal can consequently conflict with another and have different effects on the various stakeholders involved-consumers, companies, and society as a whole.

In this paper, we bring a multi-level perspective between institutions and actors into the CSR debate. Drawing parallels with established literature in organizational behavior [56], we argue that CSR efforts to address food waste should be understood as an ongoing process that involves both institutional actors (i.e., retailers) and individuals (i.e., consumers), and exists both at institutional and individual levels. Sometimes the values of these actors are monolithic and perfectly aligned, helping to point the way to relatively straightforward solutions to existing social problems. In other situations, consumer and retailer values are misaligned, just as retailer and supplier values may also be [16]. Thus, we present the issue of food waste as a wicked problem for retailers and consumers [57]. We do so because consumers do not have homogenous values that help retailers effectively meet their value-driven needs in a way that they might be able to if they treated consumers as a single institutional actor or monolithic group with uniform preferences. Rather, consumers are heterogeneous, and retailers face situations where their actions to address CSR goals may simultaneously meet the social needs of some consumers while ignoring the needs of others. We furthermore argue that the heterogeneous characteristics of consumers highlight their influential role and responsibility in whether price promotions do in fact lead to food waste at the household level. The view that consumers are responsible for the ethical consequences of their actions has received increasing attention in the past decades [58].

Despite the apparent conflicts between different CSR goals and the wicked problem encountered in CSR decisions, there is also potential for win-win situations for various goals simultaneously. It is not necessarily profitable for the retailer to induce over-purchases that exacerbate household food waste, as consumers might dislike being driven into wasting food, and thus turn away from the offending market actors. In that sense, a retailer's efforts to help consumers reduce food waste might pay off in terms of customer 
acquisition, increased customer loyalty, and an improved image, aligning profit goals with sustainability goals in a so-called business case for sustainability [59].

\section{Method}

\subsection{Literature Search Procedure}

The search for literature was limited to articles published in peer-reviewed refereed journals. The rationale for imposing this limitation is that peer-reviewed work constitutes established knowledge with the highest impact on the field [60]. Furthermore, the search scope was narrowed to articles published in English between 2007 and 2017 in order to obtain relatively recent developments in the field, which has experienced a surge in food waste-related publications within the last 8 years [61]. Initially, a series of exploratory searches were conducted in order to develop a notion of the literature on the subject of food waste and to create keywords to be used during the subsequent main search. The main search was conducted in two databases: ISI Web of Science and Scopus. The keywords included combinations of terms relating to food waste and price promotions, and the searches were implemented on the Title-Keyword-Abstract fields of the database records. The keywords would thus need to appear in either the title, the keywords, or the abstract of the record. The search keywords can be found in Tables A2 and A3 in Appendix A.

The last search was performed in December 2017. No a priori requirements were made regarding the measurement of either price promotions or measurement of food waste in the searched literature. The reason for not imposing any such requirements is that there is a somewhat wide variation in price promotions on food and in what they are called at the retail level, such as (a) multi-item offers, e.g., "3 for 2," BOGOF promotions, or any multiple number of items that are sold with another for free; (b) extra quantity for free, or bundle discounts, which provide the consumer with a certain extra quantity of the item for free; (c) Y for $€ X$, a number of items for a set amount; and (d) temporary price reductions, e.g., normal price reduced by $€ X$ [22]. Similarly, there is a great variety of methods used to operationalize food waste, ranging from self-reported food waste with the use of questionnaires, kitchen diaries, and qualitative interviews, to quantification of food waste based on actual food waste measurements [34].

\subsection{Inclusion Criteria}

The database search yielded 837 full-text records that were subsequently checked for duplicates and then screened for eligibility using the following inclusion criteria:

1. The articles should address food waste generation at the household/consumer level.

2. The articles should be based on primary data and investigate consumer-level factors related to food waste.

3. The articles should investigate, among other factors, the role of price, as well as provide information on the measurement of the respective focal variables.

A more detailed description of these inclusion criteria can be found in Table A3 in Appendix A. All identified records were screened sequentially at each step of the process, with the application of the specified inclusion criteria for each of the stages of record reduction. Records were manually screened and deemed either eligible or ineligible to proceed to the following step based on the inclusion criteria of each step.

Backward and forward bibliographic searches were conducted on the identified papers during the fourth step of the flow process (after applying inclusion criteria 1 and 2) in Google Scholar and the reference lists of each paper, respectively. Through this process, 15 additional articles were identified and added at the final step of the literature flow. After the completion of this procedure, we conducted a search within the first 10 pages of results in Google Scholar with the aim of identifying records addressing price promotions and food waste that might have been listed in a database other than ISI WoS and Scopus. The previously identified records appeared multiple times, indicating that our search had reached a saturation point. 
Eventually, after applying inclusion criteria 3, 24 records met all inclusion criteria to be included in the literature review. The procedure flow is summarized in Figure 2.

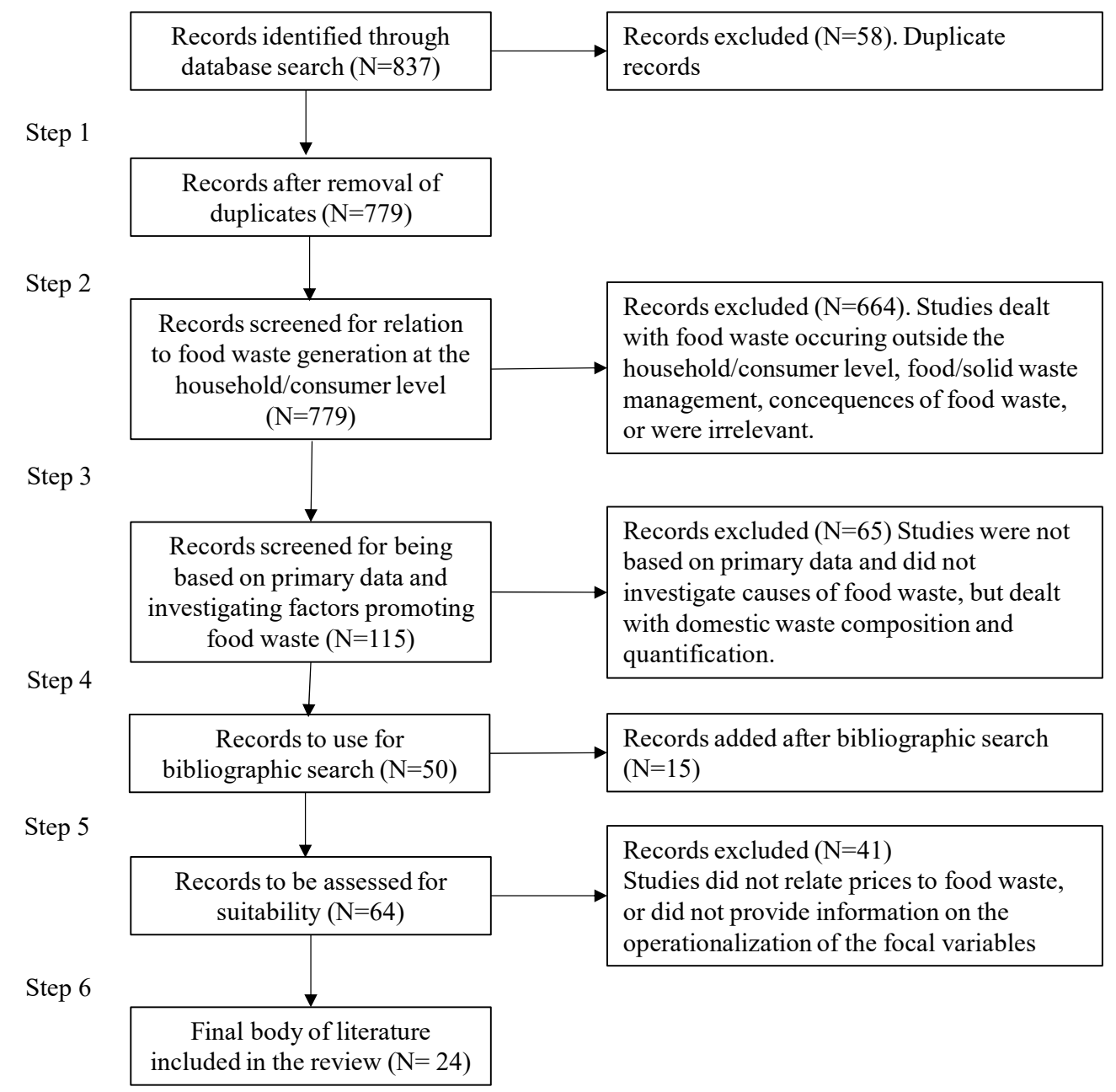

Figure 2. Schematic representation of the data collection process.

\section{Results}

The identified relationship between retail price promotions and household food waste identified in each paper is summarized in Table 1 . A complete list of the 24 articles included in the review can be found in Table A5 in Appendix A, with details regarding their method, sample, country, and main findings. Three of the identified articles are based on the same study but are described separately. In the following sections, we provide a short overview of the articles with regard to the methodological approaches and the measurement of price promotions and food waste that we found. We then present the overall results in terms of the direction of the identified relationship between price promotions and food waste. Then, we introduce each set of articles-those that suggest a positive, a negative, or no relation. Given the diverse types of studies, we give a short description of each study so that the reader can understand the context of the result. For each set of articles, we finalize with a discussion of the findings and the potential moderators of the relation between price promotions and food waste that the studies might hint at. (Three of the identified records are based on one common study; however, we present each paper as an individual study. Each of these three papers can be found in Appendix A.) We use quotation marks to indicate that variable description occurs in the same way as in the source paper. 
Table 1. Identified relationships by publication.

\begin{tabular}{|c|c|c|c|}
\hline \multirow{2}{*}{ Publication } & \multicolumn{3}{|c|}{ Relationship between Retail Price Promotions and Food Waste } \\
\hline & Positive & Neutral & Negative \\
\hline Aschemann-Witzel, et al. (2017) & & & * \\
\hline Delley, M. and Brunner, T. A. (2017) & * & & \\
\hline Ponis, et al. (2017) & * & & \\
\hline Mondejar-Jimenez et al. (2016) & * & & \\
\hline Porpino et al. (2016) & * & & \\
\hline Qi, D. and Roe, B. E. (2016) & & * & \\
\hline Sassi, et al. (2016) & & & * \\
\hline Schmidt, K. (2016a) & * & & \\
\hline Schmidt, K. (2016b) & * & & \\
\hline Yildirim, et al. (2016) & & * & \\
\hline Jörissen et al. (2015) & & & * \\
\hline Parizeau et al. (2015) & & & * \\
\hline Neff et al. (2015) & & & * \\
\hline Porpino et al. (2015) & * & & \\
\hline Setti et al. (2015) & * & & \\
\hline Farr-Wharton, et al. (2014) & * & & \\
\hline Graham-Rowe et al. (2014) & * & & \\
\hline Katajajuuri et al. (2014) & & * & \\
\hline Silvennoinen, et al. (2014) & & & * \\
\hline Ganglbauer, E. and Fitzpatrick, G. (2013) & * & & \\
\hline Fonseca, Jaime R.S. (2013) & * & & \\
\hline Evans, D. (2012a) & & * & \\
\hline Koivupuro et al. (2012) & & & * \\
\hline Williams et al. (2012) & & & * \\
\hline
\end{tabular}

\subsection{Characterization of Studies}

A total of 13 studies employed a quantitative approach and based their findings primarily on survey methodology. One study employed the physical sorting of food waste alongside a questionnaire, and another study used a combination of food waste weighing and a survey instrument. Six studies utilized qualitative methods: Two applied semi-structured interviews and ethnographic observations, whereas the remaining four employed a combination of ethnographic observations, focus groups, and photographic documentation. Finally, the remaining five studies employed a mixed methodology, both quantitative and qualitative, three of which used a kitchen diary and a questionnaire, and the two others a combination of questionnaires and interviews.

Use of a theoretical framework in the identified studies was sparse. Farr-Wharton, and colleagues [62] use the framework of the Value-Belief-Norm Theory as a lens in their approach, whereas Mondéjar-Jiménez and colleagues [63] use the Theory of Planned Behavior. Schmidt [64] chooses the integrative influence model of pro-environmental behavior to integrate perceptual, motivational, and behavioral predictors that explain household food waste behavior.

With regard to food waste measurement, two studies utilized waste sorting and the weighing of actual food waste. In most studies, researchers inquired about the frequency of food disposal and obtained estimations of the food amounts discarded. In some studies, food waste was operationalized by merging individual attitude or behavior items that are hypothesized to relate to food waste behavior into one composite variable. In the cohort of qualitative studies, the measurement of food waste differed because it was based on direct observations from the researchers, as well as on statements from the interviews.

With regard to price promotions, most of the quantitative studies used Likert scales to measure the respondents' frequency and propensity to buy food on sale in some way, without specifying the particular types of promotions. The measurement of the particular construct was diverse and depended largely on the authors' conceptualization. For exam- 
ple, Williams and colleagues [65] measure consumers' "price awareness" with two items that, according to the behavioral pricing literature, would in fact pertain to two distinct deal behaviors, price search and discount purchase behavior. In the qualitative studies, the measurement of the price promotions was based on statements from the interviews.

The included studies investigate a multitude of factors that have a potential effect on the amount of food waste in a household, and they can be broadly related to each of the following thematic units: (a) Attitudinal and psychographic factors, e.g., waste concerns, moral issues; (b) lifestyle factors, e.g., family lifestyle, convenience; (c) broader practices of household food provisioning, e.g., eating preferences, over-preparation of food; (d) shopping preferences, e.g., big supermarket chains or small local shops; (e) knowledge, e.g., when is a food product inedible, knowledge of food labeling; (f) food-related characteristics, e.g., packaging and type of food; and (g) demographic factors, e.g., income, gender, household size.

\subsection{The Relationship between Price Promotions and Food Waste}

The results of the review show that the relationship between price promotions and household-level food waste is indeed ambiguous and thus inconclusive. In total, 12 articles indicate a positive relationship between price promotions and household-level food waste. In these articles, the results suggest that price promotions are related to greater amounts of food waste. However, eight articles hint at a negative relationship between price promotions and food waste. In this case, the results of the studies indicate that consumers who are more prone to shopping for discounted food products are less likely to waste food than those who are not prone to discount shopping. Finally, the remaining four studies find no association between price promotions and food waste.

\subsection{Articles That Found a Positive Relationship between Price Promotions and Food Waste}

Upon closer inspection of the studies that conclude a positive relationship between price promotions and household food waste, some interesting findings emerge. We find that the studies can be grouped into four categories: First, those that identify a potential causal relation between the frequency of price promotion use and food waste $[47,62,63,66]$; second, those that a priori assume that price promotions lead to food waste [64,67]; third, those that identify consumer clusters characterized simultaneously by price promotion use and food waste [68,69]; and fourth, qualitative research clearly showing that "bulk buying" is discussed as a cause of food waste $[30,46,70,71]$.

Three of the studies indicate that self-reported frequent use of price promotions relates to a higher degree of self-reported food discard $[47,66]$ and has a negative influence on consumers' waste behavior [63]. A set of studies assume a priori that there is a positive relationship between price promotions and food waste and incorporate that assumption into the study framework $[64,67]$. Schmidt's studies provide evidence that price promotions and household-level food waste are conceptually associated; however, due to the exploratory nature of these studies, confirmatory evidence is necessary to further support that argument and substantiate that proposition. Two studies identify a cluster of consumers in which both a high degree of self-reported price promotion use and a high degree of food waste are found $[68,69]$. None of the research studies are based on actual measures of food waste or food waste diaries. Thus, all the above findings draw on selfreported measures. The five qualitative studies consistently find that consumers report that multi-item purchases and price promotions trigger food-waste behavior, and consumers talk about this as a source of food waste. However, the extent to which this leads to food waste appears to be, at least partly, the impression of the authors when they interpret the observations. Interestingly, none of the qualitative studies show that consumers might "talk" about using price promotions for stockpiling food, but then "not" waste any of their stocks. The quantitative studies provide some hints as to which factors might moderate the relation between purchasing price-promoted food and food waste: Mondéjar-Jiménez and colleagues [63] suggest attitude as a factor; Fonseca [68,69] suggests that a factor could be 
whether one is the main shopper or not, while Delley and Brunner's [68] study indicates that holding conservative values might be a moderating factor. The qualitative studies primarily indicate that not only a lack of food-handling capabilities but also the goal of maintaining one's identity as a good provider lead to price-promoted food being wasted. For a detailed description of the studies, see the supplementary material.

\subsection{Articles That Found a Negative Relationship between Price Promotions and Food Waste}

Upon closer inspection of the studies that conclude a negative relationship between price promotions and household food waste, some interesting findings emerge. Study methodologies can be categorized into: First, food-waste sorting and food-waste diaries identifying a negative relation; second, studies showing a negative relation in self-reported food waste; and a third group that are diverse in character.

We find that most reviewed studies that are based on either food waste sorting or food waste diaries indicate a negative relation, i.e., consumers who use promotions frequently or are price-conscious end up producing relatively low food waste $[11,65,72,73]$. Two survey studies support this finding as well $[17,74]$, and another survey study appears to show that the majority of consumers who use price promotions state that they do not waste food [75]. The studies reviewed in this section provide some hints as to which factors moderate the relation between purchasing price-promoted food and food waste: Price-oriented behavior might be related to more conscious purchase behavior and subsequent use of food, as well as to an attitude of not wanting to waste anything. For a detailed description of the studies, see the supplementary material.

\subsection{Articles That Found a Neutral Relationship between Price Promotions and Food Waste}

The studies that do not reach a conclusive result on the relationship between price promotions and household food waste are primarily quantitative in their approach. One bases its results on actual food waste measurements provided by the participants themselves [76], whereas the rest base their results on self-reported frequencies of shopping and food waste, as well as awareness and attitudes toward food waste [77,78]. The qualitative study by Evans [79] focuses on the reasons why food waste occurs and underlines that households routinely provision more food than they can find uses for, but not necessarily due to the use of price promotions. For a detailed description of the studies, see the supplementary material.

\section{Conclusions}

We conclude that the results of the literature review provide evidence that the relationship between household-level food waste and price promotions is ambiguous, as there is no clearly prevailing route in the directionality between them. We reach that conclusion based on two observations from the review. First, although a slight majority of the identified studies conclude that price promotions are positively related to food waste, evidence from a number of other studies questions this conclusion (for an overview of the direction of the findings, see Table A5). Thus, there is no clear consensus in the literature. Second, the slight majority of the studies suggesting a positive relation should be given less weight due to limitations that give grounds to interpret their conclusions with care. These limitations are as follows: Some of these studies are partly based on the built-in assumption that such a positive relationship exists per se, e.g., through the operationalization of measures. Furthermore, some of these studies clearly emphasize that a relationship exists between over-purchase and household food waste; yet, they do not necessarily assert a causal relation given they are qualitative in nature. Studies based on food waste diaries, in turn, tend to show a negative relation. Given that the waste diary is assumed to be less prone to bias, and provides a more accurate approximation of what is wasted [80], this finding gives more weight to the potential negative relation.

One possible explanation for the ambiguous picture and potentially dual nature of the investigated relationship stems from the argument that food waste is not a single 
behavior but rather an outcome within a larger complex network of antecedents [29], such as consumers' perceived budget constraints $[70,74]$, price consciousness $[17,65,76]$, and shopping habits [73]. The investigated studies hint at the existence of an array of factors within that network of antecedents that can mitigate household food waste. We therefore conclude that a thrifty attitude, price consciousness, personal values that discourage wastefulness, and household members' roles and capabilities within the food provisioning process can attenuate the amounts of household food waste (see Figure 3).

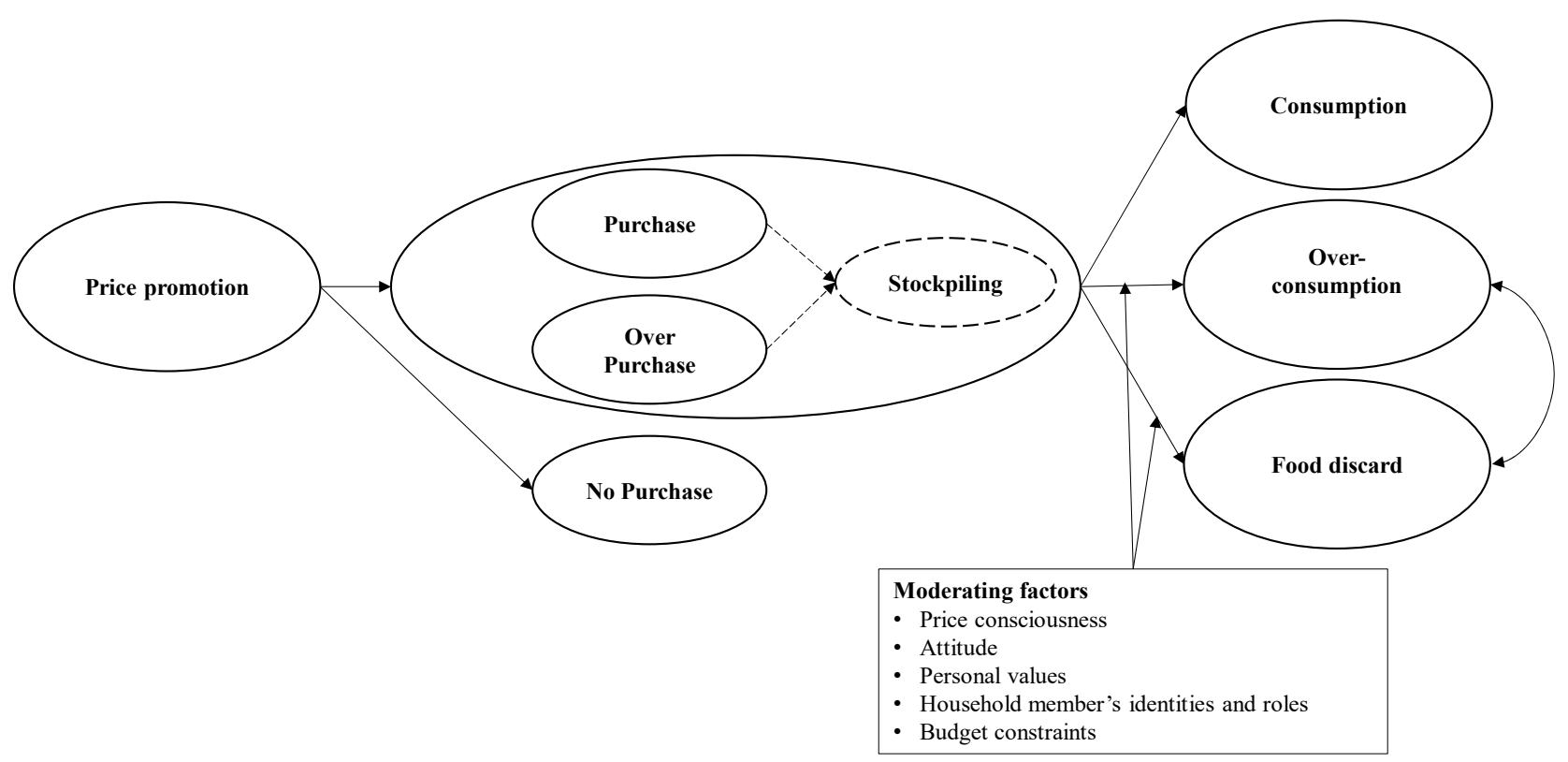

Figure 3. Conceptual framework of factors that potentially moderate the creation of household-level food waste.

In conclusion, the relationship between retailer price promotions and food waste is less clear than one might expect. We argue that this is the case because an important stakeholder is disregarded in this assumption: The consumer. Specifically, we propose that the role of retail price promotions for food waste should be viewed from a multi-level perspective [56]. If retailers attempt to address consumer food waste while treating consumers as monolithic and homogeneous actors, this may lead to unintended consequences. We explain inconsistencies in the existing literature examining price promotions and food waste, by suggesting that retailer price promotions affect consumers heterogeneously. For some consumers, price promotions encourage over-purchasing in ways that the existing criticism of price promotion suggests, ultimately contributing to food waste. Yet, for other consumers, price promotion helps them meet important economic goals, giving them access to food in ways that lead to economically sustainable outcomes. Critically, we introduce a micro-level of analysis into these more macro-level debates on CSR, suggesting that factors at the individual level explain the divergent responses to retailer actions. Thus, the debate surrounding price promotions and food waste appears to present a wicked problem $[57,81]$, where retailer efforts to address first-order socially desirable problems (i.e., reducing food waste) may lead to second-order problems (i.e., reducing economic access to food), problems that complicate efforts toward socially desirable ends.

We make several contributions to the literature. First, we contribute to the food waste literature, where it is often taken for granted that price promotions are a definite cause of food waste, by providing a more nuanced view of the role of pricing on food waste. We show that this relationship is not as strong as initially believed; rather, it is conditional upon individual characteristics that are relatively overlooked in this debate. Second, we contribute to the literature on business ethics by suggesting that issues within CSR are often wicked problems [57] where solutions to present issues differentially impact the variety of social expectations involved in CSR issues in ways that both solve and create 
problems, e.g., economic, social, environmental: See [82]. We stress the importance of introducing a multi-level perspective to the study of CSR problems so that broad institutional responses effectively consider how existing heterogeneity in consumer psychological reactions contributes to disparate outcomes in CSR policies. Moreover, we also contribute to the literature on business ethics by showing that the assumption "price promotions lead to food waste" is an example of simplifying a relation and neglecting the role of the consumer in a CSR action, and that the consumer heterogeneity explains why research findings on the relation are ambiguous. We therewith underline the importance of CSR that accounts for and acknowledges consumer responsibility.

Finally, we derive implications for business ethics in practice. We show that the CSR perspective expressed by retailers who decide to abolish certain price promotions excludes the important role of the consumer as an active agent. We thus argue that this view should be redefined to include consumers' social responsibility as well [55]: When retailers decide on CSR actions against food waste, they should do so after considering what characterizes the consumers they serve and how they act. The findings allow retailers to make more informed CSR decisions, allowing for a better understanding of the consequences of their decisions on the economic, social, and environmental outcomes. We derive recommendations of practical utility for responsible retail marketing practices and future directions for research. We propose that there can be cases in which retail price promotions might cause food to be wasted, as the dominant criticism suggests; however, we also propose that individual characteristics have a crucial influence on food waste avoidance behavior, thus potentially blurring the picture. Therefore, it becomes crucial to explore the various factors that might play a role in moderating the relationship between instructional efforts toward CSR and outcomes that match set goals.

\section{Future Research Directions}

An important point to consider is that the majority of the included studies investigate the creation of food waste from the perspective of the research subjects, i.e., the consumers. The qualitative studies investigate food waste and its relationship to price promotions by relying on consumers' own perceptions of the directionality of this relationship. The quantitative studies rely on self-reported deal-shopping and food waste behaviors. Given the sensitivity of the topic of food waste, in combination with respondents' " ... desire to avoid embarrassment and project a favorable image to others" [83], the studies' conclusions on the nature and directionality of this relationship can become biased. This caveat raises a question regarding the reliability of the results and furthermore calls for further studies on the subject of the relation between retail price promotions and household-level food waste. Future studies should take a direct approach and utilize direct measurements of actual purchases of food items, as well as actual deal behavior, and combine these measurements with quantitative measures of actual food waste for each household.

An additional consideration is that some researchers assume an a priori positive relationship between retail price promotions and household-level food waste. In other words, researchers consider price promotions to be a waste-promoting factor and consequently treat them as such in their studies, for example, when using the tendency to purchase multi-items as an indicator of food waste behavior. There is a need for further validation of constructs that are hypothesized to influence household food waste, either statistically through model selection techniques [84] or through application/utilization of the particular construct in a research setting.

Moreover, the independent and dependent variables are operationalized differently across the identified studies, and thus, direct comparisons between the results of these might not be substantive, particularly if the methodological diversity across the studies is also taken into consideration. The vast majority of the studies included in this review examine the relationship between food waste and price promotions in a correlational manner, and the use of theory is limited. Some of the included studies present their results purely descriptively, in percentage distributions, without providing further information on 
the analyses conducted, e.g., there is even an absence of correlation coefficients in some studies. Future research would benefit from a more homogenous operationalization of the food waste variable. We suggest that an objective measure of food waste, based on actual household food waste data, will provide the most reliable operationalization.

The results of this literature review provide evidence that the relationship in question needs to be explored further and investigated within a larger network of antecedents that influence food waste behavior. The diversity of the results is an indication that the relationship between price promotions and food waste is not ubiquitous but rather dependent on factors that lie within the individual consumer and among consumer segments with similar psychographic and demographic characteristics.

Based on the findings of these studies, as well as the methods used and the moderating factors identified, we suggest that future research should investigate whether these moderating factors exert their influence on food-waste behavior via a study measuring actual food waste. Moreover, departing from the findings of Silvennoinen and colleagues [73], who argue that consumer thriftiness and moderation in spending may help reduce food waste, we suggest that future research should investigate whether and under which circumstances pricing and price orientation can also be utilized as a factor that can help avoid food waste. For instance, a thrifty attitude might increase the intention to purchase suboptimal foods that are otherwise wasted in the earlier stages of the supply chain or in the retail setting.

\section{Implications for Business Ethics and Recommendations for Retailers}

Our results highlight that retail price promotions are not drivers of household food waste per se, even though they have been regarded as such. Thus, the assumption that price promotions necessarily lead to food waste, which is often taken for granted, appears questionable. We, instead, find that certain consumer characteristics moderate this relationship.

Retailers, in an effort to be considered socially responsible at various levels, e.g., economic, legal, ethical, and philanthropic: See [16,82], seek to address both issues of food waste and the economic circumstances of consumers. However, what becomes apparent is that price promotions that address one goal (reducing economic burden on consumers) can cannibalize another goal (waste reduction at the household level) conditional on the characteristics of consumers. When CSR issues arise, they often force actors into social situations where the best action is unclear because it points to two different value-driven directions, forcing actors to make choices about the relative importance of the goals they pursue. Such moral problems are common regardless as to whether they are addressed by individual actors, i.e., whistleblowers [85], or broader institutions, i.e., anomie [86]. Thus, our findings have important implications for the ethics of businesses deciding for and against food price promotions, or the specific type of food pricing tactic chosen, due to the plurality and often misaligned moral values embedded within CSR decisions $[82,87,88]$. Supermarkets have been accused of triggering food waste through their pricing tactics, e.g., Stuart [19], and some have reacted by, for instance, abolishing multi-item offers across the entire retail chain [24]. Our findings, however, show that there is not necessarily proof that this is the most efficient action. Rather, such actions have disregarded the consumer's role and responsibility for the issue at hand.

From a business ethics and social responsibility perspective, we caution that it is important not to overlook the needs of consumers with limited financial resources. For them, retail price promotions are excellent conduits for getting more value from grocery shopping, either in terms of adding better food quality to their basket, such as more fresh produce, or in terms of food quantity, for instance, getting more food items per monetary unit spent [89]. Therefore, eliminating price promotions altogether based on an unfounded expectation of the societal benefit of food waste reduction would deprive this sensitive segment from an essential benefit to no avail, and thus, this approach could also be considered unethical. For instance, recent research by Noble and colleagues [90] shows that impoverished consumers redeem coupons at greater rates than higher-income consumers when taking the basket size into account. The coupon is a well-integrated price- 
promotional tool in certain markets, including the US, and often related to multi-item and BOGOF offers. Removing this promotional tool based on the questionable assumption of a positive relationship between price promotions and household food waste could therefore have social ramifications.

The challenge that consequently arises for retailers is how to accomplish the advantages of price promotions while, at the same time, minimizing the risk of food waste. To that end, retailers can implement initiatives that consider the multi-level implications, as well as the role of the individual consumer. Some examples of this are discussed in the following.

Retailers can provide elaborate information to consumers about the best storage conditions for their bulk-purchased foods bought on price promotions, so that consumers can become better at avoiding wastage of food stock. In collaboration with producers, retailers can facilitate the ease of portioning food from bulk purchases through packaging innovations, in order to account for differing household size and resulting needs. Furthermore, retailers can suggest alternative recipes so as to increase meal variety and thus better utilize multiple units of foods from multi-item offers. With the use of mobile applications, retailers can notify customers of special offers at the store, including price-reduced suboptimal foods, and help their customers to better plan their shopping trips. Moreover, retailers can apply different types of price promotions depending on whether the food has a short or long shelf life, and promotions on perishable foods can be accompanied with clear instructions that they are best consumed immediately, and which recipe could be convenient for that purpose.

In Denmark, for example, the retail chain REMA1000 has abolished multi-item offers and replaced them with discounts on single items [24]. In light of the current findings, it does not appear necessary to abolish multi-item offers altogether. An alternative would be to replace the traditional "buy one get one free" with the "buy one get one later" approach where the second item remains in the store until needed by the consumer. Besides a positive CSR-image outcome for the retailer, such an approach also creates store traffic when the second item is picked up by the consumer. This is an initiative that consumers have shown to favor [91]. In summary, our review contributes to the discussion of supermarkets' responsibility for food waste and the retailer action tackling food waste that is best in line with corporate social responsibility objectives. Instead of a clear link between price promotions and food waste, it is the characteristics of the consumer that are decisive.

Our study supports a multi-level model of CSR behavior, and a CSR view that takes into account both corporate responsibilities, as well as the consumers' role and responsibility. Given this, the case of price promotions and food waste exemplifies how CSR questions are wicked and evolving problems, issues that point to consumers as important co-actors in the success of CSR [55]. This expansive view of CSR has also been previously advocated by Vitell [55], on the grounds that it aligns corporate (i.e., profits) and consumer interests. Retailers who willingly engage in CSR but who fail to acknowledge the multi-level nature of the interactions and the consumers' role run the risk of merely performing "window dressing," and their CSR initiatives becoming eroded by this exclusion, appearing merely as a façade.

Our study raises questions of the ethical nature that retailers need to consider and relate to when developing their CSR initiatives. They need to be aware of the paradoxes and conflicts that emerge from alternative actions they put forward and be ready to compromise the conflicts that are inherent in ethical dilemmas. Our study has examined in depth a phenomenon central to the discourse of marketing ethics and CSR that can facilitate the answers to these dilemmas during the process of developing a CSR strategy. As such, this research provides a deeper understanding of the role of retail price promotions and consumer characteristics in household food waste. 
Supplementary Materials: The following are available online at https:/ /www.mdpi.com/article/10 $.3390 /$ su13074018/s1.

Author Contributions: Conceptualization, G.T., B.B.J. and J.A.-W.; methodology, G.T., B.B.J. and J.A.-W.; data curation, G.T.; writing—original draft preparation, G.T.; writing—review and editing, G.T., B.B.J., S.W.W. and J.A.-W.; project administration, B.B.J. and J.A.-W.; funding acquisition, B.B.J. and J.A.-W. All authors have read and agreed to the published version of the manuscript.

Funding: The study was conducted as part of the WASTEPROM project funded by the Aarhus University Research Foundation (AUFF).

Conflicts of Interest: The authors declare no conflict of interest.

\section{Appendix A}

Table A1. Examples of the conceptualization of food waste.

\begin{tabular}{|c|c|c|c|c|}
\hline \multirow{2}{*}{ Publication } & \multirow{2}{*}{ Description } & \multicolumn{3}{|c|}{ Conceptualization of Food Waste } \\
\hline & & Disposal in the Bin & Stockpiling & Excessive Caloric Intake \\
\hline Grandhi and Singh (2016) & $\begin{array}{c}' \ldots \text { the food brought home or prepared at } \\
\text { home but not consumed' }\end{array}$ & * & & \\
\hline Garrone et al. (2014) & $\begin{array}{l}\text {... the surplus food that is not recovered } \\
\text { to feed people, to feed animals, to produce } \\
\text { new products (e.g., jams or juices), new } \\
\text { materials (e.g., fertilizers) or energy' }\end{array}$ & * & & \\
\hline Blair and Sobal, 2006 & $\begin{array}{c}\text { '... luxus consumption is consumption } \\
\text { beyond metabolic need, resulting in caloric } \\
\text { dissipation as well as other physiological } \\
\text { and social consequences' }\end{array}$ & & & * \\
\hline Smil 2004 & $\begin{array}{c}\text {... per capita gaps between average } \\
\text { availability and actual consumption are } \\
\text { now greater than } 1000 \mathrm{kcal} / \text { day...a } \\
\text { significant part of the excessive food } \\
\text { supply is actually consumed and this } \\
\text { overeating ... leads ... to higher } \\
\text { levels of obesity' }\end{array}$ & & & * \\
\hline Evans $(2012 b)$ & $\begin{array}{l}\text { '... freezers, Tupperware, and aluminium } \\
\text { foil are typically designed to preserve food } \\
\ldots \text { they very often operate as coffins of } \\
\text { decay that play an active part in carrying } \\
\text { discarded food towards the waste stream' }\end{array}$ & & * & \\
\hline Wait and Phillips (2016) & $\begin{array}{c}\text { '... refrigerated foods often became } \\
\text { revalued as excess and binned' }\end{array}$ & & * & \\
\hline
\end{tabular}

Table A2. Keywords applied on ISI Web of Science.

((household-level food-waste OR domestic food-waste OR household* food-wast* OR consumer* food-wast* OR household*

food-loss* OR consumer* food-loss* OR "avoidable food-waste" OR household* kitchen-waste OR food-waste behavio $\$ \mathrm{r}$ household* OR food-waste behavio $\$$ r consumer* OR "food-waste prevent" OR "exces* food consum*" OR "household* food suppl $1^{*}$ OR "household calor*" OR food waste overeat* OR food-abundance wast* OR food-waste behavio $\$$ r consumer* household ${ }^{*}$

OR consumer* household* food-wast* OR food* stockpil* OR food-overconsum*) AND (food promotion* pric* OR "food promotion*" OR supermarket promotion* food* OR "in-store promotion*" OR "food sale" OR food "pric discount $^{* \prime \prime}$ OR "food discount" OR food "pric* reduction*" OR "pric*-bundl*" OR "buy one get one free" OR "special-offer" OR "retail promotion*" OR “*market* promotion*" OR food bargain* OR food "price cut*" OR food "price reduction*" OR food pric* deal* OR food* retail ${ }^{*}$ promot* OR "promotion* sale*" food OR food retail promotion* pric ${ }^{*}$ OR food bundle purchase* OR cause* OR determinant* OR driver* OR factor* OR antecedent* OR predictor* OR reason* OR impact*)) 
Table A3. Keywords applied on Scopus.

((household* "food-waste" OR "household food waste" OR "consumer food waste" OR food AND loss* OR "avoidable food waste" OR "household kitchen waste" OR "food waste prevent" OR "exces* food consum*" OR "household* food suppl*" OR "household calor" OR "overeat" OR "food-abundance" OR "food waste behavior" OR "food stockpil*" OR "food overconsum*") AND (food

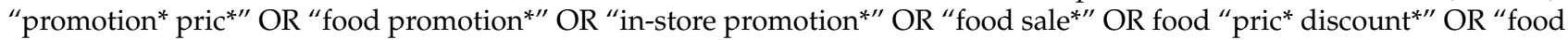
discount" OR food "pric* reduction*" OR "pric*bundl" OR "buy one get one free" OR "special-offer" OR food "*market* promotion*" OR "food bargain*" OR food "price cut" ${ }^{*}$ " OR food "pric* deal*" OR food* "retail* promot*" OR food "promotion* sale $^{* \prime}$ OR "food bundle purchase ${ }^{*}$ " OR cause* OR determinant* OR driver* OR factor* OR antecedent* OR predictor* OR reason* OR impact*))

Table A4. Description of the inclusion criteria.

1. The articles should address food waste generation at the household/consumer level. Studies that dealt with (a) food waste occurring at the post-harvest, distribution, or retail stage of the food value chain; (b) any form of food waste or solid waste management, such as composting, and valorization; (c) the environmental, societal, nutritional, and other consequences of food waste; or (d) whose subjects were irrelevant to our aim, such as depressive symptoms related to food addictions, insect consumption, etc., were excluded $(n=664)$.

2. The articles should be based on primary data and investigate consumer-level factors that potentially exacerbate food waste. Studies that (a) were literature reviews and (b) did not investigate factors that play a role in the generation of food waste but dealt with domestic waste composition and quantification, were excluded $(n=65)$.

3. The articles should investigate, among other factors, the role of price, as well as provide adequate measurement of the respective focal variables. Studies that (a) did not explicitly relate price promotions, price discounts, or bulk purchases due to a price-based promotional activity, such as 'buy one get one free', as a contributing factor for food waste, and (b) did not operationalize price promotions or food waste adequately were excluded $(n=41)$.

Table A5. Overview of included studies

\begin{tabular}{|c|c|c|c|c|}
\hline Author(s) (Year) & Methodology & Sample Size & Country(-ies) & Main Findings \\
\hline $\begin{array}{l}\text { Aschemann-Witzel, } \\
\text { et al. (2017) }\end{array}$ & $\begin{array}{l}\text { Online survey and } \\
\text { interviews }\end{array}$ & $\begin{array}{c}n=16 \text { (interviews) } \\
n=848 \text { (online survey) }\end{array}$ & Denmark & $\begin{array}{l}\text { Findings do not support the assumption } \\
\text { that the abundance created by price offers } \\
\text { might trigger food waste, but rather } \\
\text { indicate that price-focused consumers } \\
\text { might simultaneously be more focused on } \\
\text { avoiding food wastage. }\end{array}$ \\
\hline $\begin{array}{c}\text { Delley, M. and } \\
\text { Brunner, T. A. (2017) }\end{array}$ & Postal survey & $n=681$ & Switzerland & $\begin{array}{l}\text { The study identified clusters of consumer } \\
\text { profiles. Among these profiles, those } \\
\text { coined short-termists (short-term-oriented } \\
\text { consumers, } 20.9 \% \text { ), are most likely to go } \\
\text { shopping at discounters but also at } \\
\text { convenience stores, where they probably } \\
\text { carry out their frequent top-up shopping } \\
\text { trips. The short-termists' low planning } \\
\text { capabilities translate to an oversupply of } \\
\text { food, which then has to be discarded. }\end{array}$ \\
\hline Ponis, et al. (2017) & Online survey & $n=500$ & Greece & $\begin{array}{l}\text { Consumers displaying relatively frivolous } \\
\text { shopping behavior (frequent off-list and } \\
\text { promo-intensive purchasing, such as 'buy } \\
\text { one get one for free') tend to throw away } \\
\text { more food. }\end{array}$ \\
\hline $\begin{array}{l}\text { Mondejar-Jimenez } \\
\text { et al. (2016) }\end{array}$ & Online survey & $n=380$ & Italy, Spain & $\begin{array}{l}\text { Marketing and sales strategies were found } \\
\text { to have a direct, and significantly negative, } \\
\text { effect on the food waste behavior } \\
\text { of individuals. }\end{array}$ \\
\hline Porpino et al. (2016) & $\begin{array}{l}\text { Interviews, photos, } \\
\text { observations }\end{array}$ & $n=20$ & USA & $\begin{array}{l}\text { Excessive buying-a driver of food waste } \\
\text { identified in } 60 \% \text { of the families } \\
\text { investigated-indicates that point-of-sale } \\
\text { promotions are driving consumers to buy } \\
\text { more than they need. Stockpiling comfort } \\
\text { foods in abundance can promote more } \\
\text { wasted food. }\end{array}$ \\
\hline
\end{tabular}


Table A5. Cont.

\begin{tabular}{|c|c|c|c|c|}
\hline Author(s) (Year) & Methodology & Sample Size & Country(-ies) & Main Findings \\
\hline $\begin{array}{l}\text { Qi, D. and Roe, B. E. } \\
\text { (2016) }\end{array}$ & Telephone interviews & $n=500$ & USA & $\begin{array}{l}\text { Respondents are approximately equally } \\
\text { split between agreeing and disagreeing } \\
\text { with statements that food waste is } \\
\text { exacerbated by bulk and sale purchases. }\end{array}$ \\
\hline Sassi, et al. (2016) & Online survey & $n=281$ & Tunisia & $\begin{array}{c}\text { Almost half (46\%) of the respondents } \\
\text { indicated that they are drawn to special } \\
\text { promotions, (e.g., 'buy one get one free', } \\
\text { 'three for the price of two', etc.), and at the } \\
\text { same time, } 39 \% \text { of them stated that they do } \\
\text { not throw away any edible food. }\end{array}$ \\
\hline Schmidt, K. (2016) & Online survey & $n=217$ & Germany & $\begin{array}{l}\text { Avoiding impulsive purchases/buying } \\
\text { more food than currently necessary due to } \\
\text { special offers is a factor that contributes to } \\
\text { food waste. }\end{array}$ \\
\hline Schmidt, K. (2016) & Online survey & $\begin{array}{l}n=535 \text { (at three } \\
\text { time points) }\end{array}$ & Germany & $\begin{array}{l}\text { A factor that comprises behaviors related } \\
\text { to spontaneously purchasing food items } \\
\text { due to promotional activities, i.e., special } \\
\text { offers and discounts, among others, was } \\
\text { identified as an antecedent of food waste. }\end{array}$ \\
\hline Yildirim, et al. (2016) & Online survey & $n=150$ & Turkey & $\begin{array}{c}\text { Special offers, such as buy } 2 \text { get one free, } \\
\text { buy } 2 \text { and get } 30 \% \text { off, etc., may play a key } \\
\text { role in increasing food wastage, but } \\
\text { not conclusively. }\end{array}$ \\
\hline
\end{tabular}

\begin{tabular}{|c|c|c|c|c|}
\hline Jörissen et al. (2015) & Online survey & $\begin{array}{c}n=453 \text { (Karlsruhe) } \\
n=404 \text { (Ispra) }\end{array}$ & Germany, Italy & $\begin{array}{c}\text { The amount of food waste is slightly lower } \\
\text { in households that tend to buy discounted } \\
\text { groceries than in households that are not } \\
\text { interested in special offers. }\end{array}$ \\
\hline $\begin{array}{c}\text { Kate Parizeau et al. } \\
\text { (2015) }\end{array}$ & $\begin{array}{l}\text { Door-to-door surveys } \\
\text { and waste separation }\end{array}$ & $\begin{array}{c}n=68 \text { (surveys) } \\
n=222 \text { households } \\
\text { (waste sorting) }\end{array}$ & Canada & $\begin{array}{l}\text { Wasting sale food was not a common } \\
\text { occurrence (only } 2 \% \text { of respondents said } \\
\text { that they often waste sale food). }\end{array}$ \\
\hline Neff et al. (2015) & Online survey & $n=1010$ & USA & $\begin{array}{l}\text { A small percentage of respondents } \\
\text { reported buying food on sale, but overall } \\
\text { food waste is high. }\end{array}$ \\
\hline Porpino et al. (2015) & $\begin{array}{l}\text { Observation, } \\
\text { interviews, photos } \\
\text { and focus group }\end{array}$ & $n=14$ & Brazil & $\begin{array}{l}\text { Strategies used to save money—-such as } \\
\text { buying groceries in bulk (to pay a relatively } \\
\text { reduced price)—actually end up } \\
\text { generating more food waste. }\end{array}$ \\
\hline Setti et al. (2015) & Panel data & $n=1403$ & Italy & $\begin{array}{l}89 \% \text { of respondents buy foodstuffs mainly } \\
\text { when special offers are available, and food } \\
\text { purchasing when special offers are } \\
\text { available contributes to food waste. }\end{array}$ \\
\hline $\begin{array}{l}\text { Farr-Wharton, et al. } \\
\text { (2014) }\end{array}$ & $\begin{array}{l}\text { Interviews and } \\
\text { ethnographic } \\
\text { observations }\end{array}$ & $n=29$ & Australia & $\begin{array}{l}\text { Bulk-purchasing attitudes were prevalent } \\
\text { and motivated by perceived monetary } \\
\text { benefits. 'Buy bulk and save' purchases } \\
\text { were also reported to be one of the prime } \\
\text { contributors to expired-food waste. }\end{array}$ \\
\hline $\begin{array}{c}\text { Graham-Rowe et al. } \\
\text { (2014) }\end{array}$ & $\begin{array}{l}\text { Semi-structured } \\
\text { interviews }\end{array}$ & $\begin{array}{c}n=15 \text { (across } 13 \\
\text { households) }\end{array}$ & UK & $\begin{array}{l}\text { In-store marketing techniques in the form } \\
\text { of financial incentives that represented } \\
\text { 'value-for-money' were cited as a source of } \\
\text { food waste. }\end{array}$ \\
\hline Katajajuuri et al. (2014) & $\begin{array}{l}\text { Kitchen diary and } \\
\text { questionnaire }\end{array}$ & $\begin{array}{c}n=380 \text { (Kitchen diary) } \\
n=1054 \text { (questionnaire) }\end{array}$ & Finland & $\begin{array}{l}\text { The study did not find a correlation } \\
\text { between food waste levels and discounted } \\
\text { prices. Those households who bought 'buy } \\
\text { one get one free' and discounted food } \\
\text { products more often did not waste less or } \\
\text { more compared to other households. }\end{array}$ \\
\hline $\begin{array}{l}\text { Silvennoinen, et al. } \\
\text { (2014) }\end{array}$ & $\begin{array}{l}\text { Waste-weighing and } \\
\text { questionnaire }\end{array}$ & $n=380$ & Finland & $\begin{array}{c}\text { Appreciation of low food prices 'buy one } \\
\text { get one free' (BOGOF) and discounted food } \\
\text { products bought often are factors that have } \\
\text { a significant effect on the amount of } \\
\text { food waste. }\end{array}$ \\
\hline
\end{tabular}


Table A5. Cont.

\begin{tabular}{|c|c|c|c|c|}
\hline Author(s) (Year) & Methodology & Sample Size & Country(-ies) & Main Findings \\
\hline $\begin{array}{l}\text { Ganglbauer, E. and } \\
\text { Fitzpatrick, G. (2013) }\end{array}$ & $\begin{array}{l}\text { Semi-structured } \\
\text { interviews and } \\
\text { ethnographic } \\
\text { observations }\end{array}$ & $n=14$ & Austria, UK & $\begin{array}{l}\text { "Economy of scale" shopping, the purchase } \\
\text { of big quantities that are less expensive } \\
\text { than small ones, results in buying too much } \\
\text { and then in increased quantities of food } \\
\text { being thrown away. }\end{array}$ \\
\hline $\begin{array}{c}\text { Fonseca, Jaime R.S. } \\
\text { (2013) }\end{array}$ & $\begin{array}{l}\text { Online survey and } \\
\text { interviews }\end{array}$ & $\begin{array}{c}n=542 \text { (survey) } \\
n=18 \text { (interviews) }\end{array}$ & Portugal & $\begin{array}{c}\text { Approximately } 35 \% \text { of respondents can be } \\
\text { characterized as food waste citizens, who } \\
\text { have habits of responding to food } \\
\text { promotions and making } \\
\text { impulse purchases. }\end{array}$ \\
\hline Evans, David (2012) & $\begin{array}{l}\text { Ethnographic } \\
\text { observations }\end{array}$ & $n=19$ & UK & $\begin{array}{l}\text { It is not satisfactory to position food waste } \\
\text { as a matter of profligate consumers being } \\
\text { lured in by 'buy one get one free' offers. }\end{array}$ \\
\hline Koivupuro et al. (2012) & $\begin{array}{l}\text { Kitchen diary and } \\
\text { questionnaire }\end{array}$ & $n=380$ & Finland & $\begin{array}{l}\text { The amount of food waste was somewhat } \\
\text { greater in those households where BOGOF } \\
\text { 'buy one get one free' and discounted food } \\
\text { products were not often bought. }\end{array}$ \\
\hline Williams et al. (2012) & $\begin{array}{l}\text { Kitchen diary and } \\
\text { questionnaire }\end{array}$ & $n=61$ & Sweden & $\begin{array}{l}\text { On average, the households that noted } \\
\text { price to be more important wasted less } \\
\text { than the households that noted price to be } \\
\text { less important. }\end{array}$ \\
\hline
\end{tabular}

\section{References}

1. United Nations Sustainable Development Goals. 17 Goals to Transform Our World. Available online: https://www.un.org/ sustainabledevelopment/sustainable-consumption-production/ (accessed on 20 December 2017).

2. Parfitt, J.; Barthel, M.; Macnaughton, S. Food waste within food supply chains: Quantification and potential for change to 2050. Philos. Trans. R Soc. Lond. B Biol. Sci. 2010, 365, 3065-3081. [CrossRef] [PubMed]

3. Xue, L.; Liu, G.; Parfitt, J.; Liu, X.; Van Herpen, E.; Stenmarck, Å.; O'Connor, C.; Östergren, K.; Cheng, S. Missing Food, Missing Data? A Critical Review of Global Food Losses and Food Waste Data. Environ. Sci. Technol. 2017, 51, 6618-6633. [CrossRef] [PubMed]

4. Kummu, M.; de Moel, H.; Porkka, M.; Siebert, S.; Varis, O.; Ward, P.J. Lost food, wasted resources: Global food supply chain losses and their impacts on freshwater, cropland, and fertiliser use. Sci. Total Environ. 2012, 438, 477-489. [CrossRef] [PubMed]

5. Alexander, P.; Brown, C.; Arneth, A.; Finnigan, J.; Moran, D.; Rounsevell, M.D.A. Losses, inefficiencies and waste in the global food system. Agric. Syst. 2017, 153, 190-200. [CrossRef] [PubMed]

6. Gustavsson, J.; Cederberg, C.; Sonesson, U.; Otterdijk, R.V.; Meybeck, A. Global food losses and food waste. Food Agric. Organ. 2011. Available online: https://www.madr.ro/docs/ind-alimentara/risipa_alimentara/presentation_food_waste.pdf (accessed on 20 December 2017).

7. Garnett, T. Where are the best opportunities for reducing greenhouse gas emissions in the food system (including the food chain)? Food Policy 2011, 36, S23-S32. [CrossRef]

8. Gjerris, M.; Gaiani, S. Household food waste in Nordic countries: Estimations and ethical implications. Nord. J. Appl. Ethics 2013, 7, 6-23. [CrossRef]

9. Chalak, A.; Abou-Daher, C.; Chaaban, J.; Abiad, M.G. The global economic and regulatory determinants of household food waste generation: A cross-country analysis. Waste Manag. 2016, 48, 418-422. [CrossRef] [PubMed]

10. Fanelli, R.M. Using causal maps to analyse the major root causes of household food waste: Results of a survey among people from Central and Southern Italy. Sustainability 2019, 11, 1183. [CrossRef]

11. Koivupuro, H.K.; Hartikainen, H.; Silvennoinen, K.; Katajajuuri, J.M.; Heikintalo, N.; Reinikainen, A.; Jalkanen, L. Influence of socio-demographical, behavioural and attitudinal factors on the amount of avoidable food waste generated in Finnish households. Int. J. Consum. Stud. 2012, 36, 183-191. [CrossRef]

12. Hebrok, M.; Boks, C. Household food waste: Drivers and potential intervention points for design-An extensive review. J. Clean. Prod. 2017, 151, 380-392. [CrossRef]

13. Griffin, M.; Sobal, J.; Lyson, T.A. An analysis of a community food waste stream. Agric. Hum. Values 2008, 26, 67-81. [CrossRef]

14. EU. Prepatory Study on Food Waste Across EU 27: Technical Report; EU: Brussels, Belgium, 2010.

15. Fanelli, R.M.; Romagnoli, L. Annual food waste per capita as influenced by geographical variations. Annual food waste per capita as influenced by geographical variations. Riv. di Studi sulla Sostenibilità 2019, 1, 59-76. [CrossRef]

16. Devin, B.; Richards, C. Food Waste, Power, and Corporate Social Responsibility in the Australian Food Supply Chain. J. Bus. Ethics 2018, 150, 199-210. [CrossRef] 
17. Aschemann-Witzel, J.; Jensen, J.H.; Jensen, M.H.; Kulikovskaja, V. Consumer behaviour towards price-reduced suboptimal foods in the supermarket and the relation to food waste in households. Appetite 2017, 116, 246-258. [CrossRef] [PubMed]

18. De Hooge, I.E.; van Dulm, E.; van Trijp, H.C.M. Cosmetic specifications in the food waste issue: Supply chain considerations and practices concerning suboptimal food products. J. Clean. Prod. 2018, 183, 698-709. [CrossRef]

19. Stuart, T. Waste: Uncovering the Global Food Scandal; WW Norton \& Company: London, UK, 2009.

20. Loebnitz, N.; Schuitema, G.; Grunert, K.G. Who Buys Oddly Shaped Food and Why? Impacts of Food Shape Abnormality and Organic Labeling on Purchase Intentions. Psychol. Mark. 2015, 32, 408-421. [CrossRef]

21. Hegnsholt, E.; Unnikrishnan, S.; Pollman-Larsen, M.; Askelsdottir, B.; Gerard, M. Tackling the 1.6 Billion Ton Food Loss and Waste Crisis; Food Nation-State of Green: Copenhagen, Denmark, 2018.

22. WRAP. Investigation into the Possible Impact of Promotions on Food waSte; WRAP: London, UK, 2011; p. 42.

23. Aschemann-Witzel, J.; de Hooge, I.E.; Rohm, H.; Normann, A.; Bossle, M.B.; Grønhøj, A.; Oostindjer, M. Key characteristics and success factors of supply chain initiatives tackling consumer-related food waste-A multiple case study. J. Clean. Prod. 2017, 155, 33-45. [CrossRef]

24. Kulikovskaja, V.; Aschemann-Witzel, J. Food waste avoidance actions in food retailing: The case of Denmark. J. Int. Food Agribus. Mark. 2017, 29, 328-345. [CrossRef]

25. Aschemann-Witzel, J.; de Hooge, I.; Normann, A. Consumer-related food waste: Role of food marketing and retailers and potential for action. J. Int. Food Agribus. Mark. 2016, 28, 271-285. [CrossRef]

26. Evans, D.; Welch, D.; Swaffield, J. Constructing and mobilizing 'the consumer': Responsibility, consumption and the politics of sustainability. Environ. Plan. A 2017, 49, 1396-1412. [CrossRef]

27. Dahlsrud, A. How corporate social responsibility is defined: An analysis of 37 definitions. Corp. Soc. Responsib. Environ. Manag. 2008, 15, 1-13. [CrossRef]

28. Aschemann-Witzel, J.; de Hooge, I.; Amani, P.; Bech-Larsen, T.; Oostindjer, M. Consumer-Related Food Waste: Causes and Potential for Action. Sustainability 2015, 7, 6457-6477. [CrossRef]

29. Quested, T.E.; Marsh, E.; Stunell, D.; Parry, A.D. Spaghetti soup: The complex world of food waste behaviours. Resour. Conserv. Recycl. 2013, 79, 43-51. [CrossRef]

30. Porpino, G.; Wansink, B.; Parente, J. Wasted positive intentions: The role of affection and abundance on household food waste. J. Food Prod. Mark. 2016, 22, 733-751. [CrossRef]

31. Frewer, L.; Van Trijp, H. Understanding Consumers of Food Products; Woodhead Publishing: Sawston, UK, 2006.

32. Block, L.G.; Keller, P.A.; Vallen, B.; Williamson, S.; Birau, M.M.; Grinstein, A.; Haws, K.L.; LaBarge, M.C.; Lamberton, C.; Moore, E.S.; et al. The Squander Sequence: Understanding Food Waste at Each Stage of the Consumer Decision-Making Process. J. Public Policy Mark. 2016, 35, 292-304. [CrossRef]

33. Stancu, V.; Haugaard, P.; Lahteenmaki, L. Determinants of consumer food waste behaviour: Two routes to food waste. Appetite 2016, 96, 7-17. [CrossRef]

34. Bellemare, M.F.; Çakir, M.; Peterson, H.H.; Novak, L.; Rudi, J. On the Measurement of Food Waste. Am. J. Agric. Econ. 2017, 99, 1148-1158. [CrossRef]

35. FAO. Food Losses and Waste in Europe and Central Asia; FAO: Roma, Italy, 2013.

36. Grandhi, B.; Singh, J.A. What a Waste! A Study of Food Wastage Behavior in Singapore. J. Food Prod. Mark. 2016, 22, 471-485. [CrossRef]

37. Garrone, P.; Melacini, M.; Perego, A. Opening the black box of food waste reduction. Food Policy 2014, 46, 129-139. [CrossRef]

38. Blair, D.; Sobal, J. Luxus consumption: Wasting food resources through overeating. Agric. Hum. Values 2006, 23, 63-74. [CrossRef]

39. Smil, V. Improving efficiency and reducing waste in our food system. Environ. Sci. 2004, 1, 17-26. [CrossRef]

40. Evans, D. Binning, gifting and recovery: The conduits of disposal in household food consumption. Environ. Plan. D Soc. Space 2012, 30, 1123-1137. [CrossRef]

41. Waitt, G.; Phillips, C. Food waste and domestic refrigeration: A visceral and material approach. Soc. Cult. Geogr. 2016, 17, 359-379. [CrossRef]

42. Thyberg, K.L.; Tonjes, D.J. Drivers of food waste and their implications for sustainable policy development. Resour. Conserv. Recycl. 2016, 106, 110-123. [CrossRef]

43. Bell, R.; Marshall, D.W. The construct of food involvement in behavioral research: Scale development and validation. Appetite 2003, 40, 235-244. [CrossRef]

44. Jensen, B.B.; Bech-Larsen, T. Consumers' multifaceted deal knowledge in a grocery retail setting. Int. Rev. Retail Distrib. Consum. Res. 2017, 27, 61-77. [CrossRef]

45. Urbany, J.E.; Dickson, P.R.; Kalapurakal, R. Price search in the retail grocery market. J. Mark. 1996, 60, 91-104. [CrossRef]

46. Ganglbauer, E.; Fitzpatrick, G.; Comber, R. Negotiating Food Waste: Using a Practice Lens to Inform Design. ACM Trans. Comput. Hum. Interact. 2013, 20, 25. [CrossRef]

47. Ponis, S.T.; Papanikolaou, P.A.; Katimertzoglou, P.; Ntalla, A.C.; Xenos, K.I. Household food waste in Greece: A questionnaire survey. J. Clean. Prod. 2017, 149, 1268-1277. [CrossRef]

48. De Hooge, I.E.; Oostindjer, M.; Aschemann-Witzel, J.; Normann, A.; Loose, S.M.; Almli, V.L. This apple is too ugly for me! Consumer preferences for suboptimal food products in the supermarket and at home. Food. Qual. Prefer. 2017, 56, 80-92. [CrossRef] 
49. Javalgi, R.G.; La Toya, M.R. International marketing ethics: A literature review and research agenda. J. Bus. Ethics 2015, 148, 703-720. [CrossRef]

50. Friedman, M. The social responsibility of business is to increase its profits. In Corporate Ethics and Corporate Governance; Springer: Berlin, Germany, 2007; pp. 173-178.

51. Carroll, A.B.; Shabana, K.M. The business case for corporate social responsibility: A review of concepts, research and practice. Int. J. Manag. Rev. 2010, 12, 85-105. [CrossRef]

52. Carroll, A.B. The pyramid of corporate social responsibility: Toward the moral management of organizational stakeholders. Bus. Horiz. 1991, 34, 39-48. [CrossRef]

53. Carroll, A.B. Corporate social responsibility: Evolution of a definitional construct. Bus. Soc. 1999, 38, 268-295. [CrossRef]

54. Hunt, S.D.; Vitell, S. A general theory of marketing ethics. J. Macromarketing 1986, 6, 5-16. [CrossRef]

55. Vitell, S.J. A case for consumer social responsibility (CnSR): Including a selected review of consumer ethics/social responsibility research. J. Bus. Ethics 2015, 130, 767-774. [CrossRef]

56. Klein, K.J.; Kozlowski, S.W. From micro to meso: Critical steps in conceptualizing and conducting multilevel research. Organ. Res. Methods 2000, 3, 211-236. [CrossRef]

57. Head, B.W. Wicked problems in public policy. Public Policy 2008, 3, 101.

58. Giesler, M.; Veresiu, E. Creating the responsible consumer: Moralistic governance regimes and consumer subjectivity. J. Consum. Res. 2014, 41, 840-857. [CrossRef]

59. Schaltegger, S.; Lüdeke-Freund, F.; Hansen, E.G. Business cases for sustainability: The role of business model innovation for corporate sustainability. Int. J. Innov. Sustain. Dev. 2012, 6, 95-119. [CrossRef]

60. Podsakoff, P.M.; Mackenzie, S.B.; Bachrach, D.G.; Podsakoff, N.P. The influence of management journals in the 1980s and 1990s. Strateg. Manag. J. 2005, 26, 473-488. [CrossRef]

61. Chen, H.; Jiang, W.; Yang, Y.; Yang, Y.; Man, X. State of the art on food waste research: A bibliometrics study from 1997 to 2014 . J. Clean. Prod. 2017, 140, 840-846. [CrossRef]

62. Farr-Wharton, G.; Foth, M.; Choi, J.H.J. Identifying factors that promote consumer behaviours causing expired domestic food waste. J. Consum. Behav. 2014, 13, 393-402. [CrossRef]

63. Mondéjar-Jiménez, J.A.; Ferrari, G.; Secondi, L.; Principato, L. From the table to waste: An exploratory study on behaviour towards food waste of Spanish and Italian youths. J. Clean. Prod. 2016, 138 Pt 1, 8-18. [CrossRef]

64. Schmidt, K. Explaining and promoting household food waste-prevention by an environmental psychological based intervention study. Resour. Conserv. Recycl. 2016, 111, 53-66. [CrossRef]

65. Williams, H.; Wikström, F.; Otterbring, T.; Löfgren, M.; Gustafsson, A. Reasons for household food waste with special attention to packaging. J. Clean. Prod. 2012, 24, 141-148. [CrossRef]

66. Setti, M.; Falasconi, L.; Segre, A.; Cusano, I.; Vittuari, M. Italian consumers' income and food waste behavior. Br. Food J. 2016, 118, 1731-1746. [CrossRef]

67. Schmidt, K. What a Waste! Developing the Food Waste-Preventing Behaviors Scale-A Useful Tool to Promote Household Food Waste-Prevention. Int. J. Food Nutr. Sci. 2016, 3, 1-14. [CrossRef]

68. Delley, M.; Brunner, T.A. Food waste within Swiss households: A segmentation of the population and suggestions for preventive measures. Resour. Conserv. Recycl. 2017, 122, 172-184. [CrossRef]

69. Fonseca, J.R.S. A Latent Class Model to discover household food waste patterns in Lisbon city in support of food security, public health and environmental protection. Int. J. Food Syst. Dyn. 2013, 4, 184-197.

70. Graham-Rowe, E.; Jessop, D.C.; Sparks, P. Identifying motivations and barriers to minimising household food waste. Resour. Conserv. Recycl. 2014, 84, 15-23. [CrossRef]

71. Porpino, G.; Parente, J.; Wansink, B. Food waste paradox: Antecedents of food disposal in low income households. Int. J. Consum. Stud. 2015, 39, 619-629. [CrossRef]

72. Parizeau, K.; von Massow, M.; Martin, R. Household-level dynamics of food waste production and related beliefs, attitudes, and behaviors in Guelph, Ontario. Waste Manag. 2015, 35, 207-217. [CrossRef] [PubMed]

73. Silvennoinen, K.; Katajajuuri, J.-M.; Hartikainen, H.; Heikkilä, L.; Reinikainen, A. Food waste volume and composition in Finnish households. Br. Food J. 2014, 116, 1058-1068. [CrossRef]

74. Jörissen, J.; Priefer, C.; Bräutigam, K.-R. Food Waste Generation at Household Level: Results of a Survey among Employees of Two European Research Centers in Italy and Germany. Sustainability 2015, 7, 2695-2715. [CrossRef]

75. Sassi, K.; Capone, R.; Abid, G.; Debs, P.; El Bilali, H.; Daaloul Bouacha, O.; Bottalico, F.; Driouech, N.; Sfayhi Terras, D. Food wastage by Tunisian households. Int. J. Agrofor 2016, 1, 10. [CrossRef]

76. Katajajuuri, J.-M.; Silvennoinen, K.; Hartikainen, H.; Heikkilä, L.; Reinikainen, A. Food waste in the Finnish food chain. J. Clean. Prod. 2014, 73, 322-329. [CrossRef]

77. Qi, D.; Roe, B.E. Household Food Waste: Multivariate Regression and Principal Components Analyses of Awareness and Attitudes among U.S. Consumers. PLoS ONE 2016, 11, 19. [CrossRef]

78. Yildirim, H.; Capone, R.; Karanlik, A.; Bottalico, F.; Debs, P.; El Bilali, H. Food Wastage in Turkey: An Exploratory Survey on Household Food Waste. J. Food Nutr. Res. 2016, 4, 483-489.

79. Evans, D. Beyond the throwaway society: Ordinary domestic practice and a sociological approach to household food waste. Sociology 2012, 46, 41-56. [CrossRef] 
80. Van Herpen, E.; van der Lans, I.; Nijenhuis, M.; Holthuysen, N.; Kremer, S. Best Practice Measurement of Household Level Food Waste; EU: Brussels, Belgium, 2016.

81. Buchanan, R. Wicked problems in design thinking. Des. Issues 1992, 8, 5-21. [CrossRef]

82. Carroll, A.B. A three-dimensional conceptual model of corporate performance. Acad. Manag. Rev. 1979, 4, 497-505. [CrossRef]

83. Fisher, R.J. Social desirability bias and the validity of indirect questioning. J. Consum. Res. 1993, 20, 303-315. [CrossRef]

84. Pitt, M.A.; Myung, I.J. When a good fit can be bad. Trends Cogn. Sci. 2002, 6, 421-425. [CrossRef]

85. Waytz, A.; Dungan, J.; Young, L. The whistleblower's dilemma and the fairness-loyalty tradeoff. J. Exp. Soc. Psychol. 2013, 49, 1027-1033. [CrossRef]

86. Merton, R.K. Social Theory and Social Structure. (Rev. ed.); Free Press: New York, NY, USA, 1957.

87. Graham, J.; Haidt, J.; Koleva, S.; Motyl, M.; Iyer, R.; Wojcik, S.P.; Ditto, P.H. Moral foundations theory: The pragmatic validity of moral pluralism. In Advances in Experimental Social Psychology; Elsevier: Amsterdam, The Netherlands, 2013; Volume 47, pp. 55-130.

88. Rai, T.S.; Fiske, A.P. Moral psychology is relationship regulation: Moral motives for unity, hierarchy, equality, and proportionality. Psychol. Rev. 2011, 118, 57. [CrossRef]

89. Cassady, D.; Jetter, K.M.; Culp, J. Is Price a Barrier to Eating More Fruits and Vegetables for Low-Income Families? J. Am. Diet. Assoc. 2007, 107, 1909-1915. [CrossRef] [PubMed]

90. Noble, S.M.; Lee, K.B.; Zaretzki, R.; Autry, C. Coupon clipping by impoverished consumers: Linking demographics, basket size, and coupon redemption rates. Int. J. Res. Mark. 2017, 34, 553-571. [CrossRef]

91. Neff, R.A.; Spiker, M.L.; Truant, P.L. Wasted Food: U.S. Consumers' Reported Awareness, Attitudes, and Behaviors. PLoS ONE 2015, 10, e0127881. [CrossRef] 